\title{
Tanggung Jawab Perusahaan Multinasional dalam Kebakaran Hutan di Indonesia
}

\section{Chris Sostom Gintoe}

Chris Sostom Gintoe; Magister Ilmu Hukum Universitas Padjajaran, Jl. Banda No 42, Bandung; Jawa Barat; Indonesia.

ARTICLEINFO

Article history:

Received 2019-03-09

Received in revised form

2019-05-25

Accepted 2019-07-01

Kata kunci:

Tanggung Jawab, Perusahaan

Multinasional, Kebakaran Hutan,

Hukum Lingkungan, Hukum

Internasional.

Keywords:

Responsibilities, Multinational

Companies, Forest Fires,

Environmental Law, International

Law.

\section{Citation:}

Gintoe, C. (2019). Tanggung Jawab Perusahaan Multinasional dalam Kebakaran Hutan di Indonesia. Jurnal Cakrawala Hukum, 10(1). doi:10.26905/idjch.v10i1.2808

Corresponding Author:

Chris Sostom Gintoe

E-mail address: tomgintoe@gmail.com

DOI: https://doi.org/10.26905/idjch.v10i1.2808.

\section{Abstrak}

Indonesia sebagai negara pengekspor asap juga menyebabkan kerugian di negara tetangga dan dampak kabut asap tersebut berdampak pada perekonomian, pariwisata dan kesehatan di negara-negara sekitar. Berdasarkan hal tersebut maka dalam penulisan ini menguraikan identifikasi masalah sebagai berikut pertama, bagaimanakah kedudukan perusahaan multinasional menurut Undang-Undang Republik Indonesia Nomor 40 Tahun 2007 tentang Perseroan Terbatas. Kedua, bagaimanakah bentuk tanggung jawab perusahaan multinasional dalam hal terjadinya kebakaran hutan di Indonesia dalam perspektif hukum lingkungan internasional. Metode yang digunakan dalam penelitian ini adalah metode yuridis normatif yang bersifat deskriptif. Kasus kebakaran hutan di Indonesia yang dilakukan oleh perusahaan multinasional tersebut dapat dibebani tanggung jawab sesuai dengan ketentuan dimana perusahaan tersebut beroperasi. Hal tersebtu dikarenakan hukum internaisonla bleum mampu secara langsung membebankan tanggung jawab hukum kepada korporasi dan masih diperlukan kewenangan negara dalam memberi sanksi hukum sebagai perantara. Hukum internasional masih belum beranjak dari penggunaan teori klasik negarasentris. Ketentuan pidana dan administrasi dapat dibgunakan dalam penuntutan suatu korporasi.

\section{Abstract}

Indonesia as a country that exports smoke also causes losses in neighboring countries and the impact of the haze has an impact on the economy, tourism and health in surrounding countries. Based on this, in this paper describes the problem identification as follows first, what is the position of multinational companies according to the Republic of Indonesia Law Number 40 of 2007 concerning Limited Liability Companies. Second, what is the form of responsibility of multinational companies in terms of forest fires in Indonesia in the perspective of international environmental law. The method used in this study is a normative juridical method that is 


\section{Tanggung Jawab Perusahaan Multinasional dalam Kebakaran Hutan di Indonesia}

Chris Sostom Gintoe

descriptive. The case of forest fires in Indonesia carried out by multinational companies can be burdened with responsibility in accordance with the conditions in which the company operates. This is because the internal law of Bleum is able to directly impose legal responsibility on corporations and state authority is still needed to sanction the law as an intermediary. International law has still not moved from the use of the classical negocentric theory. Criminal and administrative provisions can be used in prosecuting a corporation.

\section{Latar Belakang}

Perekonomian negara-negara, khususnya negara berkembang sangat membutuhkan arus modal asing yang benyak untuk mendukung perekonomian yang dapat terus berjalan dan bertumbuh. Pilihan pertumbuhan perekonomian untuk menjalankan roda perekonomian ini salah satunya adalah dengan mengundang perusahaan multinasional untuk berinvestasi atau melakukan kegiatan perekonomian yang dapat menunjang hidup rakyat dalam negara-negara berkembang. Kehadiran perusahaan multinasional dalam perekonomian negara - negara sering kali dimudahkan dengan memberikan fasilitas dan kemudahankemudahan dalam melakukan investasi asing di dalam negaranya.

Negara yang mengundang masuk investor asing dengan perusahaan-perusahaan multinasionalnya berharap bahwa perusahaan-perusahaan tersebut dapat menjadi agent of development (Sumantoro, 1984). Dengan modal dan teknologi yang mereka miliki diharapkan perusahaanperusahaan tersebut dapat mengelola sumber daya alam yang ada di negara tuan rumah (host state), meratakan pembangunan, meningkatkan ekspor, meningkatkan pemasukan pajak, membuka lapangan pekerjaan, memberikan teknologi-teknologi baru serta meningkatkan kualitas sumber daya manusia host state.

Salah satu tujuan investasi perusahaan multinasional secara khusus di Indonesia adalah pada sektor kehutanan. Hutan di Indonesia adalah sumber kehidupan bagi banyak orang, bahkan bukan saja bagi masyarakat Indonesia saja namun secara luas hutan memiliki potensi yang luar biasa sebagai paru-paru dunia serta menjaga keseimbangan lingkungan. Potensi tersebut mengandung banyak manfaat yang lain bagi kehidupan dan populasi manusia jika dikelola secara benar dan bijaksana.

Hutan adalah suatu kesatuan ekosistem berupa hamparab lahan berisi sumber daya laam hayati yang di dominasi pepohonan dalam persekutuan lama lingkungannya yang satu dengan lainnya tidak dapat dipisahkan. Pengertian tersebut di ambil menurut Undang-Undang Republik Indonesia Nomor 41 Tahun 1999 Pasal 1 ayat 2.

Kelestarian dan keberlanjutan kehutanan harus dijaga sebagai salah satu penentu penyangga kehidupan dan sumber kesejahteraan rakyat agar kualitasnya tidak semakin menurun, harus di jaga terus menerus keeksistesiannya, agar tetap abadi dan ditangan orang yang berbudi pekerti luhur, berkeadilan, berwibawa, transparan dan profesional serta bertanggung jawab (Muis dkk, 2011).

Kasus kebakaran hutan di Idnoensia adalah sebuah bencana tahunan yang selalu saja rutin terjadi. Sedangkan kasus ini selalu saja terjadi di daerah Sumatra dan Kalimantan (Putra, 2018). Hal ini karena tata kelola hutan yang buruk di Indonesia. Buruknya tata kolola hutan ini terjadi mulai dari sektor perkebunan sampai kehutanan. Hal ini diperparah dengan perizinan pembukaan lahan gambut yang mudah terbakar serta sulit dipadamkan bila terjadi kebakaran. 
Tujuan perusahaan-perusahaan asing melakukan pembakaran hutan untuk keperluan perkebunan dengan membakar lahan dimaksudkan agar lebih menghemat dan menekan biaya guna membuka lahan perkebunan yang baru. Keuntungannya yaitu perusahaan tidak perlu mengeluarkan dana tambahan yang lebih besar dalam menggunakan alat-alat berat guna membuka lahan.

Indonesia sebagai negara pengekspor asap juga menyebabkan kerugian di negara tetangga dan dampak kabut asap tersebut berdampak pada perekonomian, pariwisata dan kesehatan di negaranegara sekitar. Berdasarkan hal tersebut maka dalam penulisan ini menguraikan identifikasi masalah sebagai berikut pertama, bagaimanakah kedudukan perusahaan multinasional menurut UndangUndang Republik Indonesia Nomor 40 Tahun 2007 tentang Perseroan Terbatas. Kedua, bagaimanakah bentuk tanggung jawab perusahaan multinasional dalam hal terjadinya kebakaran hutan di Indonesia dalam perspektif hukum lingkungan internasional.

\section{Metode}

Metode yang digunakan dalam penelitian ini adalah metode yuridis normatif yang bersifat deskriptif yaitu suatu penelitian hukum yang bertujuan untuk memperoleh gambaran (deskripsi) lengkap tentang keadaan hukum yang berlaku di tempat tertentu dan pada saat tertentu, atau mengenai gejala yuridis yang ada, atau peristiwa hukum tertentu yang terjadi dalam masyarakat (Kadir, 2004).

\section{Pembahasan}

A. Kedudukan Perusahaan Multinasional Menurut Undang-Undang Republik Indonesia Nomor 40 tahun 2007 Tentang Perseroan Terbatas

Perusahaan multinasional merupakan suatu bentuk asosiasi bisnis yang paling banyak dibicarakan dalam rangka globalisasi dunia dan ekonomi.
Peran dari globalisasi sebagai ideologi dan perkembangan kebijakan peraturan terkait dengan perusahaan multinasional (Chandrawulan, 2011).

Istilah multinasional diperkenalkan pertama kali oleh David E. Lilienthal pada bulan April tahun 1960 dalam makalahnya tentang manajemen dan perusahaan yang diperuntukkan untuk acara pertemuan ilmiah yang diselenggarakan oleh Carnegie Institute of Technology on 'Management and Corporations'. Makalah Lilienthal kemudian dipublikasikan dengan istilah The Multinational Corporation (MNC). Lilienthal memberikan pengertian perusahaan multinasional sebagai perusahaan yang mempunyai kedudukan di satu negara tetapi beroperasi dan menjalankan perusahaannya berdasarkan hukum-hukum dan kebiasaan-kebiasaan negara lain (Chandrawulan, 2011).

Pakar ekonomi lebih sering menggunakan istilah Multi National Enterprise atau perusahaan multinasional, sebagaimana pernyataannya dalam meeting OECD sebagai berikut:

"Multinational Enterprise usually corporise of companies or other entities whose ownership is private, state, or mixed, established in different countries and so linked that one or more of them may be able to exercise a significant influence over the activities of others and in particular, to share knowledge and resources with the others (Sumantoro, 1987)."

Menurut Robert L. Hulbroner (Saran, 1990), yang dimaksud dengan perusahaan multinasional adalah perusahaan yang mempunyai cabang dan anak perusahaan yang terletak di berbagai negara. Demikian J. Panglaykim (1983), menyatakan bahwa perusahaan transnasional adalah suatu jenis perusahaan yang terdiri dari bermacam-macam kelompok perusahaan yang bekerja dan didirikan di berbagai negara, tetapi semuanya diawasi oleh satu pusat perusahaan.

Rugman menyatakan bahwa perusahaan multinasional merupakan perusahaan yang beroperasi melintasi batas negara, berproduksi di luar 
negeri selain di dalam negeri. Perusahaan multinasional ini sedikitnya berproduksi di negara asing. Sedangkan menurut Michael dan Shaked, perusahaan diklasifikasikan sebagai multinasional berdasarkan dua kondisi. Pertama, perusahaan harus memiliki foreign sales account minimal $20 \%$ dari pendapatan. Kedua, investasi modal langsung paling tidak terdapat pada enam negara di luar negaranya (Rahmawati, 2008).

Undang-Undang Nomor 40 Tahun 2007 (selanjutnya UUPT) tidak dikenal istilah perusahaan multinasional, karena di dalam UUPT hanya mengenal istilah perseroan terbatas yang terdapat pada Pasal 1 angka 1 UUPT sebagai berikut:

“Perseroan Terbatas yang selanjutnya disebut Perseroan, adalah badan hukum yang merupakan persekutuan modal, didirikan berdasarkan perjanjian, melakukan kegiatan usaha dengan modal dasar yang seluruhnya terbagi dalam saham dan memenuhi persyaratan yang ditetapkan dalam undang-undang ini serta peraturan pelaksanaan."

Bertitik dari Pasal 1 angka 1 UUPT diatas, tidak dikenal mengenai pengertian dari perusahaan multinasional, tetapi hanya dikenal perseroan terbatas sebagai badan hukum di Indonesia yang didirikan berdasarkan perjanjian, melakukan kegiatan usaha dengan modal dasar yang seluruhnya terbagi dalam saham yang lahir melalui proses hukum dalam bentuk pengesahan dari Pemerintah.

Bentuk perusahaan multinasional terdiri atas beberapa bagian yang sangat diperlukaan dalam menentukan dan membedakan hubungan hukum diantara bagian-bagian tersebut berkaitan dengan kegiatan perusahaan multinasional. Bagian-bagian dari perusahaan multinasional yang melaksanakan kegiatan perusahaannya yaitu (Chandrawulan, 2011): a. Induk perusahaan (parent company) Induk perusahaan adalah suatu perusahaan memiliki dan mengawasi penanaman modal asing secara langsung, biasanya memiliki anak perusahaannya yang dinamakan perusahaan affiliated di dua negara atau lebih negara tempat modal ditanam. Induk perusahaan merupakan pusat pembuat keputusan perusahaan yang menentukan tujuan-tujuan dan pengawasan-pengawasan berjalannya suatu sistem secara keseluruhan dalam satu perusahaan. Keputusan-keputusan utama yang dibuat oleh induk perusahaan dapat berupa pendirian anak atau cabang perusahaan atau akuisisi perusahaan, penentuan negara yang akan dijadikan lokasi penanaman modal asing langsung, banyaknya produksi yang akan dibuat, produksi-produksi campuran yang dilakukan diantara anak perusahaan, komposisi transfer produksi antar anak perusahaan dan penentuan pasar nasional yang akan dilayani oleh anak-anak perusahaan.

b. Kantor cabang atau cabang perusahaan (branch atau branch office)

Kantor cabang atau cabang perusahaan adalah suatu kantor yang merupakan bagian dari induk perusahaan yang beroperasi di negara induk perusahaan atau di luar negeri atau di negara tempat modal ditanam dan tidak terdiri sendiri atau mempunyai status perusahaan. Tinjauan segi hukum cabang perusahaan atau kantor cabang ini hanya merupakan perpanjangan secara fisik dari induk perusahaan dan tidak mempunyai status hukum yang terpisah dari induk perusahaan.

c. Kantor pusat (the headquarters atau head office) Kantor pusat adalah suatu kantor yang didirikan oleh suatu perusahaan multinasional yang mempunyai kedudukan sebagai kantor pusat atau pusat organisasi suatu perusahaan multinasional yang biasanya berlokasi di negara tempat induk perusahaan itu berada atau di negara penanam modal. 
d. Anak perusahaan affiliate (daughter atau affiliated company)

Anak perusahaan affiliate atau daughter company adalah perusahaan holding dari penanaman modal di luar negeri, tanpa melihat bentuk hukum, tetapi biasanya merupakan suatu anak perusahaan atau suatu subsidiary atau perusahaan gabungan atau associate, yang didirikan berdasarkan hukum dari negara tempat modal asing itu dilakukan. Pendiriannya sama dengan pendirian suatu perusahaan domestik di negara yang bersangkutan, biasanya berbentuk suatu perseroan terbatas.

e. Anak perusahaan subsidiary

Anak perusahaan adalah sebuah perusahaan yang dikendalikan oleh sebuah perusahaan yang terpisah yang lebih tinggi (induk perusahaan). Perusahaan yang dikendalikan disebut sebagai perusahaan korporasi, atau perseroan terbatas, dan dalam beberapa kasus dapat menjadi pemerintah atau perusahaan milik negara.

Pendirian perusahaan multinasional yang didirikan di Indonesia tetap mengacu kepada Undang-Undang Nomor 40 Tahun 2007 tentang Perseroan Terbatas yang selanjutnya disebut UUPT sebagaimana yang terdapat di dalam Pasal 7 sampai dengan 14 UUPT. Kedudukan hukum perusahaan multinasional menurut Undang-Undang Nomor 40 Tahun 2007 Tentang Perseroan Terbatas (selanjutnya UUPT) sebagai badan hukum di Indonesia karena perusahaan multinasional yang berkedudukan di Indonesia berbentuk perseroan terbatas.

Pasal 1 angka 1 UUPT sebagai berikut:

"Perseroan Terbatas yang selanjutnya disebut Perseroan, adalah badan hukum yang merupakan persekutuan modal, didirikan berdasarkan perjanjian, melakukan kegiatan usaha dengan modal dasar yang seluruhnya terbagi dalam saham dan memenuhi persyaratan yang ditetapkan dalam undang-undang ini serta peraturan pelaksanaan."

Ketentuan yang terdapat pada Pasal 1 angka 1 UUPT secara jelas menyebut bahwa perusahaan multinasional yang ada di Indonesia dalam hal ini berbentuk perseroan terbatas merupakan badan hukum. Namun status badan hukum perusahaan multinasional ini tidak otomatis diperoleh saat perusahaan multinasional didirikan, status badan hukum perusahaan multinasional yang berbentuk perseroan terbatas tersebut menurut Pasal 7 ayat (4) UUPT diperoleh pada tanggal diterbitkannya Keputusan Menteri mengenai pengesahan badan hukum perseroan.

Perusahaan multinasional sebagai badan hukum mandiri di Indonesia berdasarkan ketentuan Pasal 1 angka 1 UUPT diatas, karena lahir melalui proses hukum. Elemen pokok yang melahirkan suatu perusahaan multinasional sebagai badan hukum berdasarkan Pasal 1 angka 1 UUPT adalah (Harahap, 2013): Merupakan persekutuan modal; Didirikan berdasarkan perjanjian; Melakukan kegiatan usaha; Lahirnya perusahaan multinasional melalui proses hukum dalam bentuk pengesahan dari Pemerintah.

Jadi proses kelahirannya sebagai badan hukum, mutlak di dasarkan pada Keputusan Pengesahan oleh Menteri. Hal itu ditegaskan pada Pasal 7 ayat (2) UUPT, yang berbunyi:

"Perseroan memperoleh status badan hukum pada tanggal diterbitkannya Keputusan Menteri mengenai pengesahan badan hukum perseroan."

Badan hukum perusahaan multinasional merupakan pendukung hak dan kewajiban, yang dapat mengadakan perbuatan hukum dengan pihak lain. Perusahaan multinasional yang berbentuk perseroan terbatas memiliki kekayaan sen- 


\section{Tanggung Jawab Perusahaan Multinasional dalam Kebakaran Hutan di Indonesia}

Chris Sostom Gintoe

diri, yang terpisah dari kekayaan pengurus atau pendirinya. Segala kewajiban hukumnya dipenuhi dari kekayaan yang dimilikinya itu (Muhammad, 2006).

Kedudukan perusahaan multinasional sebagai badan hukum di Indonesia dihadapkan dengan doktrin atau ajaran umum (de heersende leer) tentang badan hukum, maka unsur-unsur badan hukum sesuai dengan de heersende leer seperti adanya kekayaan terpisah, adanya tujuan tertentu, adanya kepentingan tersendiri, dan adanya organisasi yang teratur (Muhammad, 2006). UUPT, pengaturan tentang hal tersebut diatur dengan jelas, dan dalam standar akta pendirian perusahaan multinasional yang berbentuk perseroan terbatas, klausula tersebut merupakan syarat mutlak yang harus ada dalam anggaran dasar perseroan sebagaimana diatur dalam Pasal 15 UUPT.

Perusahaan multinasional yang berbentuk perseroan terbatas memiliki status badan hukum, sesuai dengan Pasal 3 ayat (1) UUPT, maka pemegang saham perseroan terbatas tidak bertanggung jawab secara pribadi atas perikatan yang dibuat atas nama perseroan serta tidak bertanggung jawab atas kerugian perseroan melebihi nilai saham yang telah dimilikinya.

Kedudukan hukum perusahaan multinasional di Indonesia menurut UUPT adalah sebagai badan hukum biasa yang berbentuk perseroan terbatas. Perseroan terbatas yang kepemilikan sahamnya bisa dimiliki oleh asing dan dimiliki oleh Indonesia, bisa juga kepemilikan sahamnya dimiliki sepenuhnya oleh Indonesia tetapi memiliki cabang ataupun anak perusahaan di negara lain. Perusahaan multinasional dalam menjalankan kegiatan usahanya memiliki hubungan hukum dengan anak perusahaan atau induk perusahaannya yang berada di negara lain. Hubungan antara induk dengan anak perusahaan multinasional tidak dikenal didalam UUPT, hubungan antara induk dengan anak adalah hubungan secara ekonomi, secara hukum hubungan induk dengan anak perusahaan adalah sebagai badan hukum mandiri. UUPT mengatur mengenai kepemilikan saham di perseroan terbatas yang diatur dalam Pasal 84 .

Hubungan hukum yang timbul antara induk perusahaan dengan anak perusahaannya merupakan hubungan antara pemegang saham (induk perusahaan) dengan anak perusahaan. Hubungan hukum tersebut diatur secara jelas dalam anggaran dasar anak perusahaan dengan memperhatikan ketentuan yang berlaku. Sebagai contoh suatu anak perusahaan untuk dapat melakukan tindakan hukum tertentu harus mendapat persetujuan Rapat Umum Pemegang Saham (termasuk induk perusahaan sebagai pemegang saham mayoritas). Tindakan tertentu tersebut antara lain adalah melakukan penyertaan pada perusahaan lain, menerima pinjaman atau memberikan pinjaman pada perusahaan lain; melakukan perjanjian dengan pihak ketiga. Segala sesuatu tindakan hukum anak perusahaan yang berhubungan dengan anggaran dasar harus mendapat persetujuan dari induk perusahaan. Oleh karenanya organisasi dan manajemen induk perusahaan diatur sebagaimana layaknya perseroan terbatas biasa yaitu di dalam anggaran dasar induk perusahaan tersebut. Induk perusahaan melakukan pengawasan terhadap anak perusahaan sebatas posisinya sebagai pemegang saham dan sebatas diatur dalam anggaran dasar anak perusahaan.

Hubungan antara induk perusahaan dengan anak perusahaan menyebabkan terbentuknya perusahaan kelompok. Perusahaan kelompok ada apabila lebih dari satu perusahaan yang secara yuridis mandiri tunduk pada satu pimpinan bersama. Dengan demikian jelas bahwa dalam suatu perusahaan kelompok ada salah satu perusahaan berkedudukan sebagai pimpinan sentral untuk mengendalikan perusahaan-perusahaan yang bergabung. Dampak dari hubungan yang timbul antara induk perusahaan dengan anak perusahaan didalam perusahaan kelompok adalah karena penguasaan sebagian besar saham pada anak. Hubungan yang 
timbul karena induk perusahaan menanamkan saham pada anak-anak perusahaannya baik secara langsung maupun melalui pengambilalihan saham perusahaan lain.

Perusahaan kelompok dapat terjadi melalui penggabungan, peleburan, dan pengambilalihan perseroan. Pengertian penggabungan (merger), peleburan (konsolidasi), dan pengambilalihan (akuisisi) diatur dalam Pasal 122 sampai dengan Pasal 134 UUPT.

Induk perusahaan dan anak perusahaan mempunyai anggaran dasar sendiri-sendiri, karena perusahaan-perusahaan tersebut harus menjalankan usaha seperti yang telah ditetapkan dalam anggaran dasarnya masing-masing. Anggaran dasar perseroan terbatas merupakan hukum positif bagi perseroan terbatas itu yang apabila dilanggar akan mengakibatkan transaksi yang dibuat menjadi batal (Widjaja, 1994).

\section{B. Bentuk Tanggung Jawab Perusahaan Multi- nasional dalam Hal Terjadinya Kebakaran hutan di Indonesia dalam Perspektif Hukum Lingkungan Internasional}

Perusahaan multinasional adalah perusahaan yang kegiatan bisnisnya selain di negara induk juga tersebar di beberapa negara lain yaitu negara penerima yang mayoritas adalah negara-negara berkembang. Negara induk memiliki pengaturan lingkungan yang kuat, berbeda halnya dengan perusahaan multinasional yang beroperasi dinegara berkembang, perusahaan tersebut cenderung melakukan pencemaran lingkungan. Penegakkan hukum terhadap pengaturan lingkungan yang lemah di negara berkembang seringkali dimanfaatkan oleh perusahaan multinasional tersebut.

Saat ini hukum internasional belum mampu secara langsung membebankan tanggung jawab hukum korporasi, dan masih diperlukan kewenangan negara dalam memberi sanksi hukum sebagai perantara. Hal ini, hukum internasional masih belum beranjak dari penggunaan teori klasik yang menganut pahan negara-sentris (Wahyunto, 2019).

Hukum internasional biasanya bersifat soft law, tidak mengatur bagaimana menegakkan hukum atas perusahaan multinasional untuk menjaga integritas lingkungan. Namun di dalam hukum internasional dikatakan apabila perusahaan multinasional melanggar kewajiban tersebut saat beraktifitas di negara penerima, maka harus tunduk pada pengaturan negara penerima tersebut, sehingga mekanisme pengaturan dan penegakkan hukum adalah melalui pengaturan hukum nasional.

Tanggung jawab negara timbul didasarkan adanya tindakan atau kegiatan yang dilakukan di dalam wilayah suatu negara atau di bawah pengawasan negara tersebut yang berdampak negartif bagi lingkungan tanpa mengenal batas negara. Pertanggung jawaban negara dalam hukum lingkungan internasional, khususnya permasalahan tentang polusi lintas batas.

Bentuk - bentuk pertanggung jawaban negara diatur dalam pasal-pasal draf ILC. Ganti rugi atau reparition diatur dalam pasal 31. Bentuk-bentuk ganti rugi dapat berupa (Putra, 2018):

a. Restitution (pasal 35), kewajiban mengembalikan keadaan yang dirugikan seperti semula.

b. Compensation (pasal 36), kewajiban ganti rugi berupa materi atau uang.

c. Satisfaction (Pasal 37), penyesalan dan permintaan maaf resmi.

Pasal 5 Undang-Undang Republik Indonesia Nomor 25 Tahun 2007 tentang Penanaman Modal, perusahaan multinasional yang akan melakukan kegiatan di Indonesia wajib membentuk badan hukum Indonesia, khsususnya dalam bentuk perseroan terbatas. Dengan demikian keberaadaan perusahaan multinasional di Indonesia harus tunduk pada hukum nasional Indonesia. Oleh karena itu, perusahaan multinasional yang beroperasi di Indonesia dengan membentuk badan hukum per- 
seroan terbatas berdasarkan hukum nasional Indonesia jelas menjadi subyek hukum nasional Indonesia.

Perusahaan multinasional dalam rangka melakukan kegiatan usahanya melalui anak perusahaan atau perseroan terbatas yang didirikan oleh perusahaan multinasional berdasarkan hukum Indonesia mendapat perlindungan hukum dan perlakuakn yang sama dengan perusahaan-perusahaan nasional. Hal ini diatur secara tegas dalam Pasal 6 Undang-Undang Republik Indonesia Nomor 25 Tahun 2007 tentang Penanaman Modal sebagai berikut:

1. Pemerintah memberikan perlakuan yang sama kepada semua penanam modal yang berasal dari negara manapun yang melakukan kegiatan penanaman modal di Indonesia sesuai dengan ketentuan peraturan perundangundangan.

2. Perlakuan sebagaimana dimaksud pada ayat 1 tidak berlaku bagi penanaman modal dari suatu negara yang memperoleh hak istimewa berdasarkan perjanjian dengan Indonesia.

Dengan demikian, maka jelaslah bahwa kepentingan perusahaan multinasional yang melakukan aktivitasnya dalam rangka menanamkan di Indonesia menurut hukum Indonesia mendapat pengakuan dan perlindungan yang seimbang dengan perusahan-perusahaan nasional (Putra, 2018).

Undang-Undang Republik Indonesia Nomor 32 Tahun Tahun 2009 Tentang Perlindungan dan Pengelolaan Lingkungan Hidup, penegakkan hukum dibidang lingkungan hidup dapat diklasifikasikan kedalam 3 kategori yaitu:

1. Penegakkan hukum lingkungan dalam kaitannaya dengan hukum administrasi / tata usaha negara.

2. Penegakkan hukum lingkungan dalam kaitannya denga hukum perdata.

3. Penegakkan hukum lingkungan dalam kaitannya dengan hukum pidana
Sanksi administrasi merupakan sanksi pertama yang diberikan dalam penegakkan hukum lingkungan. Jika sanksi ini tidak efektif, barulsah sanksi perdata hingga sanksi pidana sebagai sanksi terakhhir/terberat dipergunakan. Apabila ternyata tidak mampu menghentikan pelanggaran yang terjadi maka diupayakan penyelesaian sengketa melalui mekanisme alternatif diluar pengadilan dalam bentuk musyawarah/perdamaian/negosiasi/mediasi (Erdiansyah, 2014). Apabila upaya yang dilakukan menemui jalan buntu baru dapat digunakan instrumen penegakkan hukum pidana lingkungan hidup.

Korporasi sebagai badan hukum memiliki identitas hukum tersendiri. Identitas hukum suatu korporasi atau perusahaan terpisah dari identitas hukum para pemegang sahamnya, direksi maupun organ-organ lainnya. Kaidah hukum perdata, jelas ditetapkan bahwa suatu korporasi atau badan hukum merupakan subyek hukum perdata dapat melakukan aktifitas jual beli, dapat membuat perjanjian atau kontrak dengan pihak lain, serta dapat menuntut atau dituntut dipengadilan dalam hubungan keperdataan.

Penyelesaian secara yuridis dapat ditempuh oleh pemerintah dengan memberikan sanksi terhadap pelaku atau pengusaha/investor yang melakuakn penebangan disertai pembakaran hutan dengan alasan telah melakukan pencemaran lingkungan hidup, yang dapat digolongkan dalam tindak pidana yaitu (Erdiansyah, 2014):

1. Suatu bentuk perbuatan yang dilakuakn manusia dan/atau badan yang bertentangan dengan aturan di dalam hukum perundangundangan yang berlaku.

2. Tindak pidana perusahaan yang dilakukan subyek hukum sebelumnya telah dirumuskan didalam undang-undang yang mengandung pidana khusus antara lain ditegaskan bahwa pelakunya dapat dipidana.

Pasal 50 ayat 1, 2 dan 3 Undang-Undang Republik Indonesia Nomor 41 Tahun 1999 Jo. 
Undang-Undang Indonesia Nomor 19 Tahun 2004 terdapat ketentuan/rumusan suatu perbuatan dapat dianggap sebagai suatu tindak pidana korporasi. Penjelasan Pasal 50 ayat 1 dirumuskan bahwa yang dimaksud dengan orang adalah subyek hukum baik secara pribadi, badan hukum, maupun badan usaha. Prasarana perlindungan hutan yang tidka boleh dirusak antara lain, pagar-pagar batas kawasan hutan, ilaran api, menara pengawas dan jalan pemeriksaan. Dilarang merusak sarana perlindungan hutan, seperti alat pemadam kebakaran, tanda larangan dan alat angkut.

Undang-Undang Pertanggung Jawaban Korporasi, khususnya dalam hukum pidana, terdapat berbagai macam perumusannya yang ditempuh. Ada tiga sistem kedudukan korporasi dalam hukum pidana yakni:

1. Pengurus korporasi sebagai pembuat dan pengurus yang bertanggung jawab.

2. Korporasi sebagai pembuat dan pengurus yang bertanggung jawab

3. Korporasi sebagai pembuat yang bertanggung jawab.

Undang-Undang Nomor 19 Tahun 2004 Tentang Tanggung Jawab Korporasi menegaskan bahwa, tindak pidana yang dilakukan oleh dan/ atau atas nama badan hukum atau badan usaha, yang bertanggung jawab adalah pengurusnya, baik sendiri - sendiri maupun bersama-sama. Mengingat dalam penjelasan Pasal 50 ayat 1 dirumuskan bahwa yang dimaksud dengan orag adalah subyek hukum baik secara pribadi, badan hukum maupun badan usaha.

Ketentuan piadan dapat dibgunakan dalam penuntutan suatu korporasi. Ketentuan tersebut juga dapat digunakan dalam peraturan yang berhubungan dengan lingkungan hidup seperti Ordonansi Gangguan Stb. 449 Tahun 1927 dengan konsekuensi ancaman pidana ringan, seperti:

1. Badan hukum dapat dikenakan sanksi pidana dalam perkara kerusakan atau pencemaran lingkungan;
2. Delik lingkungan perlu dirumuskan dalam pengertian yang terkandung dalam undangundang lingkungan hidup guna memudahkanpenyelesaian perkara pengadilan.

3. Ketentuan pidana dalam dalam berbagai peraturan perundang-undangan lingkungan perlu ditinjau kembali dan disesuaikan dengan pasal 22 undang-undang nomor 32 tahun 2009 tentang perlindungan dan pengelolaan lingkungan hidup.

4. Keberhasilan pengelolaan lingkungan hidup secara terpadu memerlukan kerjasama yang serasi antara badan legislatif, eksekutif dan yudikatif.

Sanksi pidana dalam Pasal 50 ayat 1, 2, dan 3 dapat dijatuhkan kepada badan hukum atau badan usaha dengan ancaman pidana penjara paling lama 10 tahun dan denda paling banyak Rp 5.000 .000 .000 ,- dan ditambah $1 / 3$ dari pidana yang dijatuhkan.

Dengan pelaku kejahatannya adalah badan hukum, sistem strict liability dapat diterapkan dimana pertanggung jawabannya dalam hal ini tidak berdasarkan pada kualitas konsep kesalahan, melainkan menitik beratkan pada perbuatan pidana / kejahatan telah terjadi (Erdiansyah, 2014).

Kaitannya dengan pembakaran hutan di Indonesia sacara tegas tercantum dalam Pasal 49 Undang-Undang Republik Indonesia Nomor 41 Tahun 1999 Tentang Kehutanan bahwa, "pemegang hak atau izin bertanggung jawab atas terjadinya kebakaran hutan di areal kerjanya". Ketentuan tersebut, dapat diambil kesimpulan bahwa sistem yang dipergunakan dalam pasal tersebut adalah sistem strict liability. Itu artinya, apabila telah terjadi kebakaran hutan yang dilakukan dengan sengaja atau tidak sengaja/kealpaan diarela $\mathrm{HPH}$ yang dikuasai oleh suatu perusahaan, maka secara otomatis perusahaan atau badan hukum itulah yang harus bertanggung jawab. 


\section{Simpulan}

Kabakaran hutan yang terjadi di Indonesia bisa di sebut sebagai pelanggaran hukum lingkungan internasioanl yang serius. Pencemaran udara akibat pencemaran hutan sangat bertentangan dengan prinsip-prinsip hukum lingkungan internasional. Diantaranya prinsip Sic Utere Tuo ut alienum non laedes yang menegaskan bahwa suatu negara dilarang melakukan atau mengijinkan dilakukannya kegiatan yang dapat merugikan negara lain, serta prinsip good neighbourliness mengatakan bahwa kedaulatan wilayah suatu negara tidak boleh diganggu oleh negara lain. Hukum internasional masih belum beranjak dari penggunaan teori klasik negarasentris.

Undang-Undang Republik Indonesia Nomor 32 Tahun 2009 Tentang Perlindungan dan Pengeloaan Lingkungan Hidup telah diatur mengenai bentuk sanksi yang dapat diberikan kepada para oknum yang melakukan pengrusakan lingkungan hidup. Sanksi tersebut dapat diklasifikasikan kedalam 3 kategori yaitu: Penegakkan hukum lingkungan dalam kaitannya dengan hukum administrasi/hukum tata usaha negara. Penegakkan hukum lingkungan dalam kaitannya dengan hukum perdata Penegakkan hukum lingkungan dalam kaitannya dengan hukum pidana.

\section{Daftar pustaka}

Chandrawulan, An An. 2011. Hukum Perusahaan Multinasional Liberalisasi Hukum Perdagangan Internasional dan Hukum Penanaman Modal. Bandung. Alumni.

Erdiansyah. 2014. Implementasi Pertanggung Jawaban Pidana Korporasi Pembakaran Hutan dan Lahan di Provinsi Riau. Volume 4 No 3 September.

Harahap, Yahya. 2013. Hukum Perseroan Terbatas. Jakarta. Sinar Grafika.

Muhammad, Abdul Kadir. 2006. Hukum Perusahaan Indonesia. Bandung. Citra Aditya Bakti.

Muis, Yusuf Abdul dan Muhammad Taufik Makarao. 2011. Hukum Kehutanan di Indonesia. Jakarta. Rineka Cipta.
Panglaykim, J. 1983. Perusahaan Multinasional Dalam Bisnis Internasional, Jakarta. CSIS.

Putra, Agustia. 2018. Kepentingan Indonesia Tidak meratifikasi ASEAN Agreement On Transboundary Haze Pollution Tahun 2002-2012. https:// repository.unri.ac.id/xmlui/bitstream/handle/ 123456789/3225/Jurnal\%20Imiah. \%20Agustia \% 20Putra \% 20(0901120048) \% 20Hubungan \% 20Internasional.pdf?sequence=1 diakses pada 12 Januari 2018.

Putra, Akbar Kurnia. 2018. Tranzboundary Haze Pollution Dalam Perspektif Hukum Lingkungan Internasional. Jurnal Ilmu Hukum. https:// media.neliti.com/media/publications/43315-IDtransboundary-haze-pollution-dalam-perspektifhukum-lingkungan-internasional.pdf Hlm 99 diakses Pada 14 Januari 2018.

Rahmawati, Santi. 2008. Perbedaan Struktur Modal Perusahaan Multinasional dan Perusahaan Domestik. Depok, Tesis Program Pasca Sarjana Fakultas Ekonomi Universitas Indonesia.

Saran, K. 1990. Perusahaan Multinasional Dalam Tata Ekonomi Internasional Baru. Makasar. FH UNHAS.

Sumantoro. 1984. Bunga Rampai Permasalahan Penanaman Modal dan Pasar Modal/ Problems of Investment in Equities and in Securities. Binacipta.

Sumantoro. 1987. Kegiatan Perusahaan Transnasional. Jakarta. Gramedia.

Undang-Undang Republik Indoensia Nomor 32 Tahun 2009 tentang Perlindungan dan Pengelolaan Lingkungan Hidup.

Undang-Undang Republik Indoensia Nomor 40 Tahun 2007 tentang Perseroan Terbatas.

Undang-Undang Republik Indoensia Nomor 41 Tahun 1999 tentang Kehutanan.

Wahyunto, dkk. 2013. Prospek Pemanfaatan Lahan Gambut Untuk Perkebunan Kelapa Sawit di Indonesia. Vol. 12 Nomor 1, Juni 2013. http://perkebunan. Litbang.pertanian.go.id/?p=7977 diakses pada 13 Januari 2018.

Widjaja, I. G. Rai. 1994. Pedoman Dasar Perseroan Terbatas (PT). Jakarta. Pradnya Paramitha. 